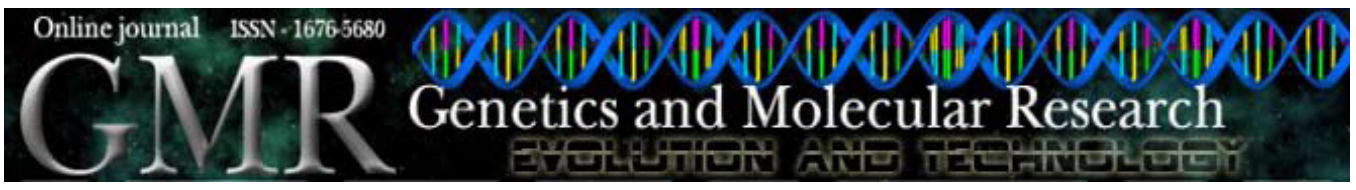

\title{
Dietary carotenoid-rich pequi oil reduces plasma lipid peroxidation and DNA damage in runners and evidence for an association with MnSOD genetic variant - Val9Ala
}

\author{
A.L. Miranda-Vilela ${ }^{1}$, A.K. Akimoto ${ }^{1}$, P.C.Z. Alves ${ }^{1}$, L.C.S. Pereira ${ }^{2}$, \\ C.A. Gonçalves ${ }^{3}$, M.N. Klautau-Guimarães ${ }^{1}$ and C.K. Grisolia ${ }^{1}$ \\ ${ }^{1}$ Departamento de Genética e Morfologia, Laboratório de Genética, \\ Instituto de Ciências Biológicas, Universidade de Brasília, Brasília, DF, Brasil \\ ${ }^{2}$ Laboratório Sabin de Análises Clínicas, Brasília, DF, Brasil \\ ${ }^{3}$ Departamento de Ciências Fisiológicas, Instituto de Ciências Biológicas, \\ Universidade de Brasília, Brasília, DF, Brasil \\ Corresponding author: A.L. Miranda-Vilela \\ E-mail: mirandavilela@unb.br; analuisamv@uol.com.br
}

Genet. Mol. Res. 8 (4): 1481-1495 (2009)

Received September 6, 2009

Accepted October 2, 2009

Published December 15, 2009

\begin{abstract}
Physical training induces beneficial adaptations; however, exhausting exercise increases reactive oxygen species generation, resulting in damage to DNA and tissues. Pequi (Caryocar brasiliense), a fruit of the Brazilian Cerrado, contains a carotenoid-rich oil. We investigated whether pequi oil had antioxidant effects in runners. Evaluations were made after outdoor races before and after ingestion of $400 \mathrm{mg}$ pequi-oil capsules for 14 days. Blood samples were taken after races and submitted to comet and TBARS assays and biochemical analyses of creatine kinase (CK), aspartate aminotransferase (AST) and alanine aminotransferase (ALT). To determine if the protective effects of pequi-oil were influenced by antioxidant enzyme genotypes, MnSOD (-Val9Ala), CAT (-21A/T)
\end{abstract}


and GPX1 (Pro198Leu) gene polymorphisms were also investigated. Pequi oil was efficient in reducing tissue injuries evaluated for AST and ALT, particularly in women, and in reducing DNA damages in both sexes. Except for CK levels, the results were influenced by MnSOD genotypes; heterozygous excess was related to less DNA damage, tissue injury and lipid peroxidation, besides presenting a better response to pequi oil against exercise-induced damage.

Key words: Caryocar brasiliense; Exercise-induced damage; Biochemical markers; TBARS assay; Comet assay; Antioxidant enzyme polymorphisms

\section{INTRODUCTION}

Aerobic organisms continuously produce reactive oxygen species (ROS), mainly as a result of normal oxidative metabolism in the mitochondria (Ferreira and Matsubara, 1997; Urso and Clarkson, 2003; Traber, 2006). Under normal circumstances, ROS are neutralized by an elaborate antioxidant defense system consisting of enzymes such as catalase (CAT), manganese superoxide dismutase (MnSOD), glutathione peroxidase (GPX), and numerous non-enzymatic antioxidants (Ferreira and Matsubara, 1997; Urso and Clarkson, 2003).

Physical training induces beneficial adaptations, but exhausting exercise above habitual intensity or training can produce an imbalance between ROS and antioxidants, which is referred to as oxidative stress. ROS can cause oxidative cell injury, such as membrane, protein and DNA peroxidation, as well as muscular injuries with consequent inflammatory processes. This can jeopardize performance, as a result of overtraining (Urso and Clarkson, 2003; Traber, 2006; Cruzat et al., 2007; Ferreira et al., 2007; Radak et al., 2007). Exhausting exercise also promotes increased oxidative stress in the heart, liver and other tissues and organs (Cruzat et al., 2007; Ferreira et al., 2007; Judge and Leeuwenburgh, 2007; Radak et al., 2007). The heart is affected because of high oxidative metabolic demand and large numbers of mitochondria (Ferreira et al., 2007; Judge and Leeuwenburgh, 2007). The liver and other tissues and organs are mainly affected by ischemia and reperfusion phenomena (Cruzat et al., 2007). Since during exercise, circulation is deviated to the active muscles, other tissues and organs can suffer temporary hypoxia. As a consequence, after exercise these tissues receive large amounts of oxygen, favoring ROS generation (Cruzat et al., 2007; Radak et al., 2007).

In humans, for ethical and logistic reasons, the evidence for exercise-induced damage has been essentially studied in blood, in both plasma and blood cells (Ferreira et al., 2007). Increases in cytosolic proteins such as aspartate aminotransferase (AST), alanine aminotransferase (ALT) and creatine kinase (CK) in blood after exercise reflects cellular injury and can be used as an exercise-induced damage marker (Bruce et al., 1958; Almersjö et al., 1968; Brancaccio et al., 2007). AST is used to evaluate muscular, myocardium, erythrocyte, hepatic, renal, and pancreatic cell injuries (Bruce et al., 1958), while increased ALT levels indicate hepatic lesions (Almersjö et al., 1968). Total CK is the most widely used biochemical marker to evaluate muscular cell injury, especially for determining the effects of exhausting exercises in healthy individuals (Brancaccio et al., 2007; 
Foschini et al., 2007). Strenuous exercise that damages skeletal muscle cells results in increased total serum CK (Brancaccio et al., 2007).

The implication that ROS play an important role in exercise-induced tissue damage first appeared in the literature in the late 1970's (Ji and Leichtweis, 1997); oxidative stress has been measured by several tests, among them, the thiobarbituric acid reactive substances (TBARS) assay (Clarkson and Thompson, 2000; Urso and Clarkson, 2003). This technique is used to evaluate lipid peroxidation in blood through measurement of TBARS, such as malondialdehyde, a byproduct of lipid peroxidation (Wasowicz et al., 1993; Clarkson and Thompson, 2000). Because strenuous exercise has been demonstrated to induce DNA damage in peripheral leukocytes, the comet assay could be used to evaluate this damage (Mastaloudis et al., 2004; Collins, 2009). Although this is not the only way to measure oxidative DNA damage, it is one of the most sensitive and accurate, and it is a valuable tool for population monitoring, for example in assessing the role of oxidative stress in human disease, and monitoring the effects of dietary antioxidants (Collins, 2009).

Many potentially significant genetic variants related to oxidative stress have already been identified, including single nucleotide polymorphisms (SNP) Va19Ala in the mitochondrial targeting sequence of the MnSOD gene (NCBI, refSNP ID: rs 1799725), -21A/T in the promoter region of the CAT gene (NCBI, refSNP ID: rs7943316) and Pro198Leu of the GPX1 gene (NCBI, refSNP ID: rs 1050450), among others (Forsberg et al., 2001). The effect of these variations has not yet been clarified; however, most of the polymorphisms result in changes in the levels or the activities of those enzymes, which can lead to reduction in protection against oxidative stress (Bastaki et al., 2006).

Antioxidant supplementation can prevent exercise-induced damages in those athletes who exercise strenuously and surpass their endogenous antioxidant defenses (Ji and Leichtweis, 1997). Nutritional supplements have been widely studied, in order to determine if they reduce the deleterious effects of extenuating exercise, among which vitamin $\mathrm{E}$, vitamin $\mathrm{C}$, creatine, and glutamine supplementation are included (Clarkson and Thompson, 2000; Cruzat et al., 2007). However, no study has examined individually the antioxidant roles of carotenoids or carotenoid-rich dietary food or supplements; only $\beta$-carotene $(30 \mathrm{mg})$ has been tested in a mixture with vitamins C (1000 mg) and E (592 mg) (Clarkson and Thompson, 2000; Urso and Clarkson, 2003; Cruzat et al., 2007).

Pequi (Caryocar brasiliense) is a typical tree of the Brazilian Cerrado, a savanna-like biome. Its fruit is well known in regional cookery, in popular medicine and for its high nutritional value. Since pequi fruit pulp oil contains various carotenoids, including $\beta$-carotene, lycopene, $\zeta$-carotene, cryptoflavin, $\beta$-cryptoxanthine, anteraxanthine, zeaxanthine, mutatoxanthine, violanxanthine, lutein, and neoxanthine (Ramos et al., 2001; Azevedo-Meleiro and Rodriguez-Amaya, 2004; Oliveira et al., 2006; Lima et al., 2007), we decided to investigate whether pequi oil can provide protective antioxidant effects for runners, after preclinical and toxicological tests in mice (Miranda-Vilela et al., 2008).

\section{MATERIAL AND METHODS}

\section{Study design and participants}

The tests of the possible protective effects of pequi oil were conducted from $\mathrm{Au}-$ 
gust 2007 to April 2008. Volunteers of both genders ( 75 men and 49 women, 15 to 67 years old) were recruited from high schools, colleges, universities, clubs, and companies in Brasília (Brazilian Federal District). The selection criterion used for the runners was that they could run at least $4000 \mathrm{~m}$. They participated in two races, before and after ingestion of $400 \mathrm{mg}$ pequi-oil capsules per day for 14 consecutive days. The choice of this daily ingestion took into account the maximum daily dose of provitamin A carotenoids recommended by the National Agency for Sanitary Surveillance (ANVISA) and the published data on pequi (Ramos et al., 2001; Azevedo-Meleiro and Rodriguez-Amaya, 2004; Oliveira et al., 2006; Lima et al., 2007).

The races before and after ingestion of pequi oil were run outdoors on flat tracks, under the same environmental conditions, and the athletes could choose the distance that they would cover (4-21 km), according to their type, intensity and length of weekly training; both races for each athlete were the same distance. The time needed by each athlete to finish the races was similar in the two races. No volunteer was excluded because he or she was taking other antioxidant supplements; the effect of these other supplements was also examined. The volunteers were informed about the purpose of the study and all signed an informed written consent. All were free to withdraw at any time during the study. After the first race, they received the capsules and were instructed to take them for 14 days during or immediately after lunch until the second race.

The protocol was approved by the Research Ethics Committee for the Health Sciences Faculty of the University of Brasília and by the National Commission for Ethics in Research (CONEP), \#0.001668/2005-18.

\section{Preparation of the capsules}

Pequi fruit was obtained in natura from the local markets of Brasília and surrounding areas. The internal mesocarp was peeled or grated to obtain the pulp, which was packed in a covered pot and frozen at $-86^{\circ} \mathrm{C}$. Pequi pulp oil was extracted by cold maceration using chloroform as a solvent. The extract was submitted to evaporation under reduced pressure for solvent removal and dried under a high vacuum. Pequi pulp oil was incorporated in Aerosil (colloidal silicon dioxide) q.s.p., so that the users ingested a daily dose of $400 \mathrm{mg}$ pequi oil, and its relative composition is shown in Table 1. The capsule production was patented as number PI0601631-6 (National Institute of Industrial Property - INPI).

\begin{tabular}{|c|c|c|c|c|c|}
\hline \multicolumn{3}{|c|}{$\begin{array}{c}\text { Fatty acids }^{1} \\
(\% \text { pequi fruit pulp oil) }\end{array}$} & \multicolumn{3}{|c|}{$\begin{array}{c}\text { Carotenoids }^{2} \\
(\mathrm{mg} / 100 \mathrm{~g} \text { pequi fruit pulp oil) }\end{array}$} \\
\hline Saturated & Mono-unsaturated & Poly-unsaturated & Pro-vitamin A & Lycopene & Total \\
\hline $\begin{array}{l}\text { Palmitic } 41.78 \\
\text { Stearic } 1.28\end{array}$ & $\begin{array}{c}\text { Oleic } 54.28 \\
\text { Palmitoleic } 0.67\end{array}$ & $\begin{array}{l}\text { Linoleic } 1.36 \\
\text { Linolenic } 0.51\end{array}$ & $6.26-11.5$ & $1.12-2.08$ & $6.75-28.66$ \\
\hline
\end{tabular}

Araquidic 0.12

${ }^{2}$ Ramos et al., 2001; ${ }^{2}$ Azevedo-Meleiro and Rodriguez-Amaya, 2004; ${ }^{2}$ Oliveira et al., 2006; ${ }^{2}$ Lima et al., 2007; ${ }^{1}$ Miranda-Vilela et al., 2009. 


\section{Procedures and measurements}

Blood samples were drawn and mixed with EDTA immediately after the races. Blood samples were used to check for DNA damage by comet assay (single-cell gel electrophoresis) and for antioxidant enzyme polymorphisms; serum samples were analyzed for AST, ALT, CK, and TBARS.

\section{Comet assay}

The comet assay (alkali method) was carried out according to Singh et al. (1988), with a few modifications. Microscope slides were dipped briefly onto $1.5 \%$ hot $\left(60^{\circ} \mathrm{C}\right)$ normal melting agarose prepared in phosphate-buffered saline (PBS). The slides were dried overnight at room temperature and then stored at $4{ }^{\circ} \mathrm{C}$ until use. Subsequently, freshly collected EDTA-treated peripheral blood from each sample (20 $\mu \mathrm{L}$ ) was suspended in $120 \mu \mathrm{L} 0.5 \%$ low melting point agarose in PBS (Gibco BRL) at $37^{\circ} \mathrm{C}$ and pipetted onto microscope slides pre-coated with a layer of normal melting point agarose. This mixture was allowed to set at $4^{\circ} \mathrm{C}$ for $10 \mathrm{~min}$. Then, the slides were immersed in a freshly prepared cold $\left(4^{\circ} \mathrm{C}\right)$ lysis solution $(2.5 \mathrm{M} \mathrm{NaCl}, 100 \mathrm{mM}$ $\mathrm{Na}_{2}$ EDTA, 10 mM Tris, NaOH, pH 10.0-10.5, 1\% lauroyl sarcosine; 1\% Triton X-100 and $10 \%$ dimethyl sulfoxide were added directly before use) at $4{ }^{\circ} \mathrm{C}$ for $1 \mathrm{~h}$. After lysis, the slides were placed in an electrophoretic tank in $300 \mathrm{mM} \mathrm{NaOH}$ and $1 \mathrm{mM}$ EDTA, $\mathrm{pH}>13.0$ for $30 \mathrm{~min}$. Subsequently, electrophoresis was carried out at $25 \mathrm{~V}$,

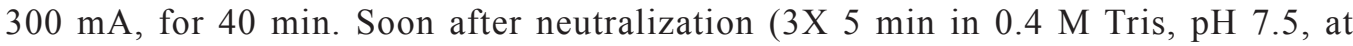
$4{ }^{\circ} \mathrm{C}$ ), the slides were stained with ethidium-bromide at $20 \mu \mathrm{g} / \mathrm{mL}$, fixed in $100 \%$ ethanol for $5 \mathrm{~min}$ and analyzed with a Zeiss Axioskop 2 fluorescence microscope (filter $510-560 \mathrm{~nm}$, barrier filter $590 \mathrm{~nm}$ ) with total magnification of 400X. All slides were duplicated. One hundred comets on each slide were scored visually as belonging to one of the five classes proposed by Collins et al. (1995) and the DNA damage was calculated according to Jaloszynski et al. (1997).

\section{Biochemical analyses}

Serum AST, ALT and CK analyses were run on an automated chemistry analyzer ADVIA 1650 (Bayer Diagnostics), using the appropriate Advia chemistry reagents and protocols. For clinical purposes, reference values for AST are in the range of 15-37 units per liter (U/L) for males and 13-31 U/L for females; for ALT, they are in the range of 10-40 U/L for males and 07-35 U/L for females, and for CK, they are up to $171 \mathrm{U} / \mathrm{L}$ for males and up to 145 U/L for females (Schumann and Klauke, 2003; Freire et al., 2008). Since athletes have higher CK values than non-athletes (Mougios, 2009), the upper reference limits for CK, and certainly for AST, could be increased.

The TBARS assay was carried out according to Wasowicz et al. (1993), with slight modifications. The TBA solution was prepared by dissolving TBA (Merck; final concentration $29 \mathrm{mmol} / \mathrm{L})$ in acetic acid $(8.75 \mathrm{~mol} / \mathrm{L}$; Merck). The stock standard solution of malondialdehyde was prepared by dissolving $480 \mu \mathrm{L}$ 1,1,3,3-tetraethoxypropane (Sigma) in $100 \mathrm{~mL}$ ethanol (Merck). Immediately before use, the solution 
was diluted in Milli-Q water to yield a working solution of $10 \mu \mathrm{mol} / \mathrm{L}$. Working aqueous solutions of EDTA $(67.3 \mathrm{mmol} / \mathrm{L})$ and $\mathrm{GSH}(32.5 \mathrm{mmol} / \mathrm{L})$ were freshly prepared immediately before use (to avoid GSH oxidation). After centrifugation (1500 $g$ for 10 min at $4{ }^{\circ} \mathrm{C}$ ), the plasma was carefully removed and EDTA and GSH were added to final concentrations of 1.34 and $0.65 \mathrm{mmol} / \mathrm{L}$, respectively. The samples were then quickly frozen in liquid nitrogen and stored at $-80^{\circ} \mathrm{C}$ until used.

For the TBARS test, $50 \mu \mathrm{L}$ plasma or an equal volume of malondialdehyde working standard solution was added to $10-\mathrm{mL}$ glass tubes containing $1 \mathrm{~mL}$ Milli-Q water, followed by a $1-\mathrm{mL}$ solution containing TBA $(29 \mathrm{mmol} / \mathrm{L})$ in acetic acid ( $\mathrm{pH}$ of the reaction mixture, 2.4-2.6), mixed, and heated in a water bath for $1 \mathrm{~h}$ at $95-100^{\circ} \mathrm{C}$. The samples were then cooled and $25 \mu \mathrm{L} 5 \mathrm{~mol} / \mathrm{L} \mathrm{HC1}$ was added (final $\mathrm{pH}$ 1.6-1.7), followed by extraction with $3.0 \mathrm{~mL}$ n-butanol and vortex mixing for $30 \mathrm{~s}$. The butanol phase was separated by centrifugation ( $1500 \mathrm{~g}$ for $10 \mathrm{~min})$ and its fluorescence was measured with a Jasco FP-777 spectrofluorometer (excitation: $525 \mathrm{~nm}$, emission: $547 \mathrm{~nm}$ ). A standard curve was prepared with malondialdehyde $(0-0.15 \mu \mathrm{mol} / \mathrm{L})$.

\section{Genotyping of antioxidant enzymes}

Peripheral blood samples were collected in Vacutainer tubes containing EDTA, and genomic DNA was isolated from the buffy-coat layer using a GFX purification kit (GE Healthcare, Buckinghamshire, England). DNA samples were stored at $-20^{\circ} \mathrm{C}$ until analysis. MnSOD, CAT and GPX1 genotypes were determined by polymerase chain reaction (PCR)-based restriction fragment length polymorphism assays performed as described, respectively, by Mitrunen et al. (2001), Ukkola et al. (2001) and Zhao et al. (2005). DNA samples (25 ng) underwent 35 amplification cycles in an MJ PTC-100 (MJ Research Inc.) PCR system. The primers (Table 2) were designed to amplify a 107-bp fragment of the MnSOD gene, a 250-bp fragment of the catalase gene and a 400-bp fragment of the GPX1 gene.

\begin{tabular}{|c|c|c|c|}
\hline Genetic markers & Primer sequences & References & Restriction enzymes \\
\hline \multicolumn{4}{|l|}{ MnSOD } \\
\hline Sense & 5'ACCAGCAGGCAGCTGGCGCCGG 3' & Mitrunen et al., 2001 & NgoMIV \\
\hline Antisense & 5' GCGTTGATGTGAGGTTCCAG 3' & & \\
\hline \multicolumn{4}{|c|}{ 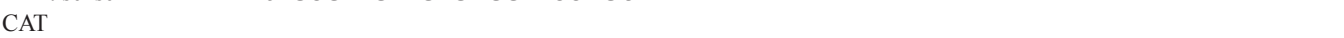 } \\
\hline Sense & 5'AATCAGAAGGCAGTCCTCCC 3' & Ukkola et al., 2001 & $\operatorname{HinfI}$ \\
\hline Antisense & 5' TCGGGGAGCACAGAGTGTAC 3' & & \\
\hline \multicolumn{4}{|l|}{ GPX1 } \\
\hline Sense & 5'AGCCCAACTTCATGCTCTTC 3' & Zhao et al., 2005 & ApaI \\
\hline Antisense & 5'CAGGTGTTCCTCCCTCGTAG 3' & & \\
\hline
\end{tabular}

MnSOD = manganese superoxide dismutase CAT = catalase; GPX1 = glutathione peroxidase 1.

The PCR product of the MnSOD gene was digested with $N g o$ MIV for $4 \mathrm{~h}$ at $37^{\circ} \mathrm{C}$. The uncut 107-bp fragment identified the MnSOD Val allele (wild). As the mutant MnSOD 
Ala allele created a restriction site for $N g o \mathrm{MIV}$, resulting in restriction fragments of 89 and $18 \mathrm{bp}$, the $\mathrm{Val} / \mathrm{Val}$ genotype yielded a 107-bp fragment; the Val/Ala genotype yielded 107-, 89- and 18-bp fragments, and the Ala/Ala yielded 89- and 18-bp fragments. The PCR product of CAT was digested with $\mathrm{HinfI}$ for $4 \mathrm{~h}$ at $37^{\circ} \mathrm{C}$. In the catalase gene, the mutant allele (T) has no HinfI restriction site, while the wild allele (A) created a restriction site, resulting in restriction fragments of 177 and $73 \mathrm{bp}$. Thus, the AA genotype yielded 177- and 73-bp fragments, the AT genotype yielded 250-, 177- and 73-bp fragments, and the TT genotype yielded a 250-bp fragment. The restriction fragments of MnSOD and CAT genes were resolved for $2 \mathrm{~h}$ at $150 \mathrm{~V}$ by electrophoresis on $6 \%$ non-denaturing polyacrylamide gels stained with silver nitrate. The PCR product of GPX1 was digested with ApaI overnight at $30^{\circ} \mathrm{C}$ and resolved for $4 \mathrm{~h}$ at $150 \mathrm{~V}$ on $10 \%$ non-denaturing polyacrylamide gels stained with silver nitrate. The Pro/Pro genotype yielded 195-, 117-, and 88-bp fragments; the Pro/ Leu genotype yielded 205-, 195-, 117-, and 88-bp fragments, and the Leu/Leu genotype yielded 205- and 195-bp fragments.

\section{Statistical analyses}

Statistical analysis was carried out using SPSS (Statistical Package for the Social Sciences), version 17.0, and SAS (Statistical Analysis System), version 9.1.3, service pack 3. To look for differences between the groups, the statistical significance was assessed by the $t$-test for dependent samples. Data are reported as means \pm SEM (standard error of the mean) and values of $\mathrm{P}<0.05$ were considered to be statistically significant. Initially, the total and gender groups were analyzed. Afterwards, the influences of age (15-19, 20-24, 25-29, 30-34, 35-39, 40-44, and 45 years old up), distance covered (4-5, $6-7,8-10$, and $16-21 \mathrm{~km})$ and use of both other antioxidant supplements and pequi oil were also examined.

The influence of MnSOD, CAT and GPX1 genotypes was investigated through the following ANOVA model: $\mathrm{Y}_{\mathrm{ijk}}=\mu+\tau_{\mathrm{i}}+\rho_{\mathrm{j}}+(\tau \rho)_{\mathrm{ij}}+\mathrm{e}_{\mathrm{ijk}}$, where $\mu$ is the general mean, $\tau_{\mathrm{i}}$ is pequi-oil effect, $\rho_{\mathrm{j}}$ is the effect of the variable analyzed, and $\mathrm{e}_{\mathrm{ijk}}$ is the random error. The Fisher LSD test was used to test for differences between the genotypes.

Allele and genotypic frequencies were estimated by gene counting, and the goodness of fit of the genotype distribution for Hardy-Weinberg equilibrium was tested by the chi-square $\left(\chi^{2}\right)$ test. Values of $\mathrm{P}>0.05$ were considered to be in Hardy-Weinberg equilibrium and were calculated by the Genepopweb statistical program, version 3.4 (http:// genepop.curtin.edu.au).

\section{RESULTS}

Pequi-oil intake resulted in reduced DNA damage and tissue injuries (AST and ALT levels) and decreased muscular injuries (CK) and lipid peroxidation (TBARS) (Figure 1), though no differences were observed in females for the latter. In the whole group, there were significant decreases in AST $(\mathrm{P}=0.0202)$, ALT $(\mathrm{P}=0.0292)$ and comet $(\mathrm{P}=0.0003)$ assays. Values fell significantly for AST $(\mathrm{P}=0.019)$ and ALT $(\mathrm{P}=0.033)$ in the women's group, and for comet assay in both sexes $(\mathrm{P}=0.0010$ for women and $\mathrm{P}=0.0382$ for men). The $\mathrm{CK}$ and TBARS assays revealed no significant differences. 

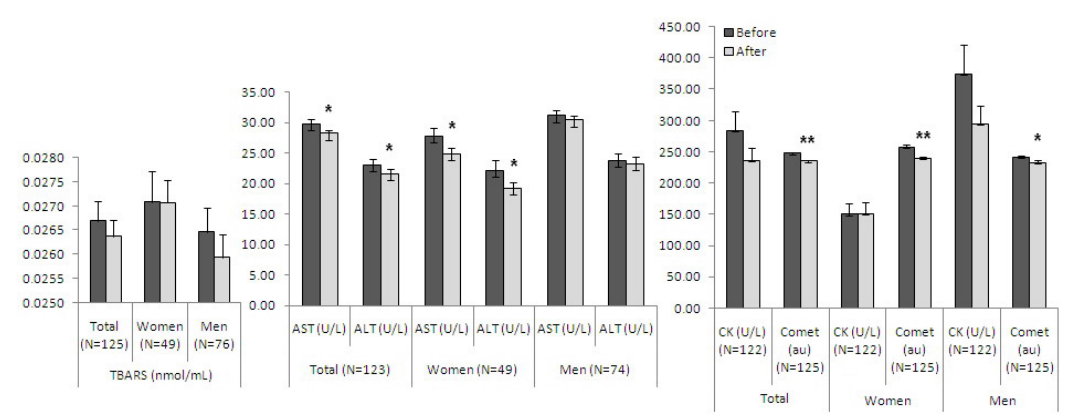

Figure 1. Influence of pequi-oil supplementation on the total and gender groups. The data correspond to the means and to the standard error of the mean (SEM). Asterisks indicate significant $(* \mathrm{P}<0.05)$ and highly significant $(* * \mathrm{P}<0.01)$ differences in the comparison of before-after values by the $t$-test for dependent samples. AST $=$ aspartate aminotransferase; $\mathrm{ALT}=$ alanine aminotransferase; $\mathrm{CK}=$ creatine kinase; $\mathrm{TBARS}=$ thiobarbituric acid reactive substances.

The influence of pequi-oil supplementation on age groups also showed a general tendency for decrease in the values for almost all age groups, except for the CK test in the age group of 45 years and older and for TBARS assay in the age group of 15-24 years old. Significant reductions in the values were found for 15-19 years old for AST $(\mathrm{P}=0.0134)$ and for 20-24 years old in comet assay $(\mathrm{P}=0.0014)$.

Concerning the influence of distance covered, there was also a general tendency for values of AST, ALT and CK tests to decrease at all distances after pequi-oil supplementation (Figure 2). TBARS and comet assays presented the same trend, except for distances of 4-5 and $16-21 \mathrm{~km}$, in that order. A significant fall in the values was found for AST $(\mathrm{P}=0.0499)$, ALT $(\mathrm{P}=0.0300)$ and TBARS $(\mathrm{P}=0.0034)$ for $6-7 \mathrm{~km}$; for comet assay it was found for 6-7 km (P $=0.0404)$ and $8-10 \mathrm{~km}(\mathrm{P}=0.0090)$.

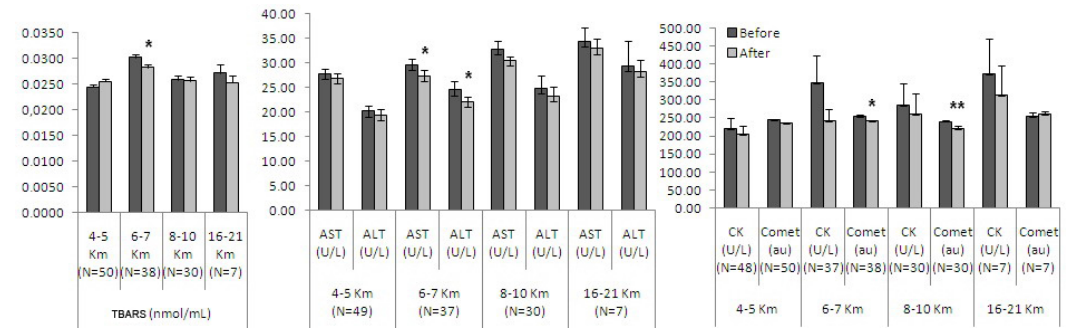

Figure 2. Influence of the distance covered $(\mathrm{km})$ before and after pequi-oil supplementation. The data correspond to the means and to the standard error of mean (SEM). Asterisks indicate significant $(* \mathrm{P}<0.05)$ and highly significant $(* * \mathrm{P}<0.01)$ differences in the comparison of before-after values by the $t$-test for dependent samples. For abbreviations, see legend to Figure 1.

The same general trend for less damage and less lipid peroxidation was also observed for use of both pequi oil and other antioxidant supplements (Table 3). Significant reductions were observed for AST in the total group $(\mathrm{P}=0.0457)$ and in the women group $(\mathrm{P}=0.0397)$. The women had a significant decrease in the ALT values $(\mathrm{P}=0.0297)$. 


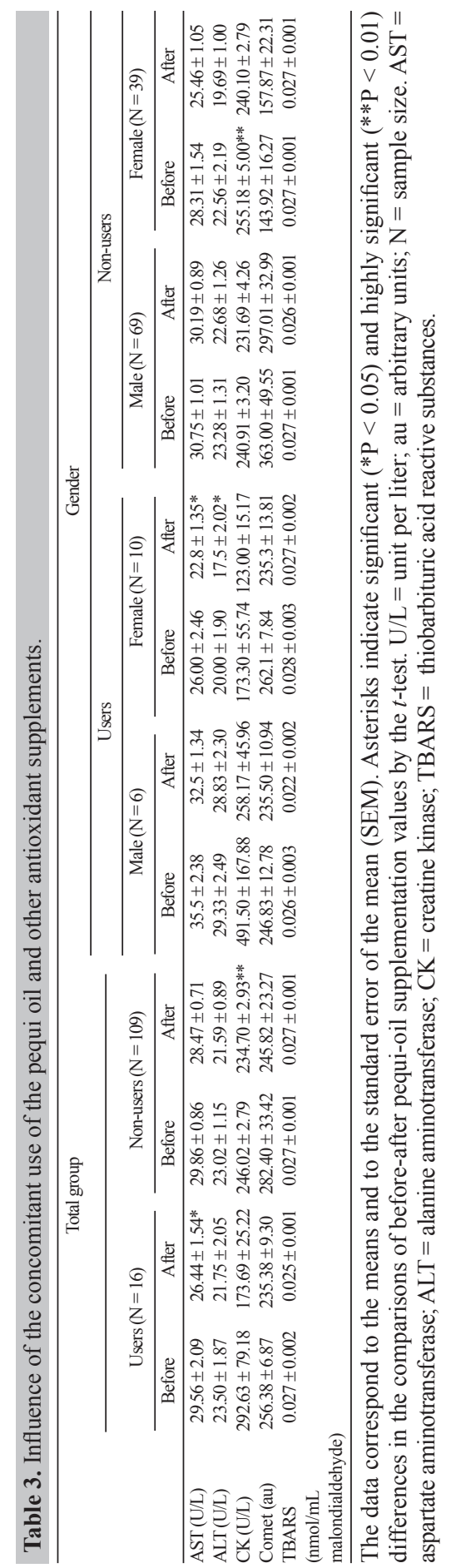


When we examined the CAT and GPX1 genes, we found no significant effect on the various assay values (ANOVA). However, MnSOD influenced ALT $(\mathrm{P}=0.0080)$, AST $(\mathrm{P}=$ $0.0122)$, the comet assay $(\mathrm{P}=0.0167)$, and TBARS $(\mathrm{P}=0.0072)$. There were differences between the genotypes Val/Val and Val/Ala for AST (Fisher LSD test, $\mathrm{P}=0.0019$ ) and ALT (P $=0.0304)$, between $\mathrm{Val} / \mathrm{Val}$ and Ala/Ala $(\mathrm{P}=0.0192)$ and Val/Ala and Ala/Ala $(\mathrm{P}=0.0048)$ for the comet assay, and between Val/Val and Val/Ala $(P=0.0032)$ for the TBARS assay. In the before-after comparisons, significant differences $(t$-test) were found for the Val/Ala genotype for AST $(\mathrm{P}=0.0150)$ and comet assay $(\mathrm{P}=0.0004)$, and for the Val/Val genotype for the TBARS assay $(\mathrm{P}=0.0047)$; the values decreased after pequi-oil treatment. The ALT levels were reduced, but the difference was not significant $(\mathrm{P}=0.0588$; Figure 3$)$.
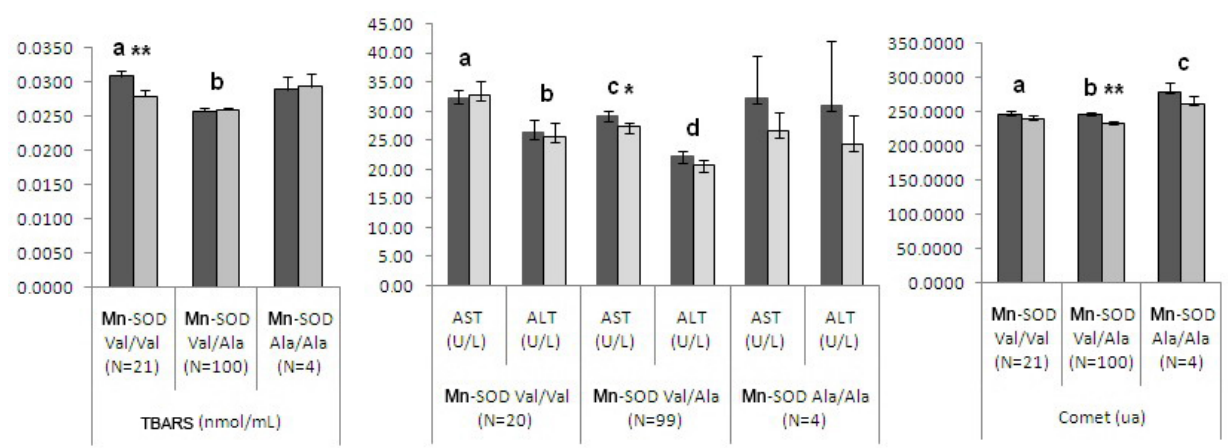

Figure 3. Influence of manganese superoxide dismutase (MnSOD) genotypes (Va19Ala polymorphism) on lipid peroxidation and oxidizing damage parameters. The data correspond to the means and to the standard error of the mean $(\mathrm{SEM})$. Asterisks indicate significant $(* \mathrm{P}<0.05)$ and highly significant $(* * \mathrm{P}<0.01)$ differences in the comparison of before-after values by the $t$-test for dependent samples. The letters $\mathrm{a}, \mathrm{b}, \mathrm{c}$, and $\mathrm{d}$ indicate significant differences detected by the Fisher LSD test between the variable's categories (genotypes): $a=$ significant compared to $\mathrm{b}(\mathrm{P}=0.0032)$ for TBARS assay; $\mathrm{a}=$ significant compared to $\mathrm{c}(\mathrm{P}=0.0019)$ for AST; $\mathrm{b}=$ significant compared to $\mathrm{d}(\mathrm{P}=0.0304)$ for ALT; $\mathrm{a}=$ significant compared to $\mathrm{c}(\mathrm{P}=0.0192)$, and $\mathrm{b}=$ significant compared to $\mathrm{c}(\mathrm{P}=0.0048)$ for comet assay. For abbreviations, see legend to Figure 1.

There was a significant deviation from Hardy-Weinberg equilibrium for the MnSOD locus $(\mathrm{P}=0.0000)$, compatible with a heterozygote excess $(\mathrm{P}=0.0000$, Table 4$)$. This locus presented an observed heterozygosity level $\left(\mathrm{H}_{\mathrm{o}}\right)$ value higher than the expected heterozygosity $\left(\mathrm{H}_{\mathrm{e}}\right)$ value, and an $\mathrm{F}_{\mathrm{IS}}$ (inbreeding coefficient) value $\left(\mathrm{F}_{\mathrm{IS}}=-0.6302\right)$ compatible with selection in favor of heterozygotes (Table 5). The genotypic distributions of CAT and GPX1 loci were in accordance with Hardy-Weinberg equilibrium ( $\mathrm{P}=0.1994$ for CAT and $\mathrm{P}=0.5269$ for GPX1 loci).

\begin{tabular}{|c|c|c|c|c|c|c|c|c|c|}
\hline & \multicolumn{3}{|c|}{ MnSOD* } & \multicolumn{3}{|c|}{ CAT } & \multicolumn{3}{|c|}{ GPX1 } \\
\hline & $\mathrm{Val} / \mathrm{Val}$ & $\mathrm{Val} / \mathrm{Ala}$ & Ala/Ala & AA & $\mathrm{AT}$ & TT & Pro/Pro & Pro/Leu & Leu/Leu \\
\hline Genotype frequencies & 0.168 & 0.800 & 0.032 & 0.184 & 0.424 & 0.392 & 0.488 & 0.400 & 0.112 \\
\hline Number of observed individuals & 21 & 100 & 4 & 23 & 53 & 49 & 61 & 50 & 14 \\
\hline Number of expected individuals & 40.33 & 61.34 & 23.33 & 19.60 & 59.80 & 45.60 & 59.17 & 53.66 & 12.17 \\
\hline
\end{tabular}

For abbreviations, see legend to Table $2 . * \mathrm{P}<0.05$. 


\begin{tabular}{|c|c|c|c|c|c|c|}
\hline \multirow[t]{2}{*}{ Genetic markers } & \multicolumn{2}{|c|}{ MnSOD } & \multicolumn{2}{|c|}{ CAT } & \multicolumn{2}{|c|}{ GPX1 } \\
\hline & Val allele & Ala allele & A allele & $\mathrm{T}$ allele & Pro allele & Leu allele \\
\hline Allele frequencies & 0.568 & 0.432 & 0.396 & 0.604 & 0.688 & 0.312 \\
\hline Observed heterozygosity $\left(\mathrm{H}_{\mathrm{o}}\right)$ & $0.800^{*}$ & & 0.424 & & 0.400 & \\
\hline Expected heterozygosity $\left(\mathrm{H}_{\mathrm{e}}\right)$ & $0.4908 *$ & & 0.4784 & & 0.4293 & \\
\hline Inbreeding coefficient $\left(\mathrm{F}_{\text {IS }}\right)$ & -0.6302 & & +0.1137 & & +0.0683 & \\
\hline
\end{tabular}

$* \mathrm{P}<0.05$. $\mathrm{P}$ values for heterozygote excess $(\mathrm{P}=0.0000)$ were generated using the Genepopweb statistical program, version 3.4. For abbreviations, see legend to Table 2.

\section{DISCUSSION}

Regular aerobic exercise expands the baseline plasma volume and there is a high variability of plasma volume changes between people and within a person due to exercise performance (Kargotich et al., 1998). In our study, the athletes ran the same distance in both races in the same time and under the same environmental conditions. Moreover, the volunteers chose the distance they would cover, according to their type, intensity and length of weekly training; there was no significant change in the daily routine of the runners between the first and the second races, except for ingestion of pequi-oil capsules. Thus, the same plasma volume expansion would be expected in the two races. Additionally, each athlete participated in the control and treatment groups, being compared in the statistical tests with him(her)self. Most exercise-induced physiological and biochemical changes have already been well studied (Ji and Leichtweis, 1997; Kargotich et al., 1998; Urso and Clarkson, 2003; Brancaccio et al., 2007; Cruzat et al., 2007; Ferreira et al., 2007), and our study did not aim to evaluate such alterations. We investigated the antioxidant effects of pequi oil for runners, after races run under the same conditions and with the same type, intensity and length of weekly training conditions (before and after taking the pequi-oil supplements). In this context, the general downward trend for AST, ALT and CK in the circulation after pequi-oil supplementation suggests protective effects of pequi oil. The significant reduction in DNA damage after supplementation corroborates this suggestion.

Epidemiological and experimental studies show that a high intake of antioxidantrich foods prevents ROS damage and that these foods can act as preventive agents against cancer and other chronic-degenerative diseases (dos Santos and Cruz, 2001; Borek, 2004). The decrease in the cytosolic proteins AST, ALT and CK in the circulation as well as DNA damage after pequi-oil supplementation reflects the decrease in exercise-induced cellular injury. The general tendency for lipid peroxidation, DNA and tissue damage to be reduced after supplementation indicates that pequi oil was efficient in protecting the runners against exercise-induced oxidative stress and damage.

It has been observed that supplementation with antioxidant vitamins $\mathrm{E}$ and $\mathrm{C}$ prevents increases in lipid peroxidation but has no apparent effect on DNA or muscle damage, suggesting that the mechanism of oxidative damage operates independently of muscle damage responses (Traber, 2006). Our results are not in accordance with this suggestion, since pequi oil both prevented increases in lipid peroxidation and decreased damages to DNA and tissues, including muscles. However, antioxidant action depends on the partial oxygen pressure $\left(\mathrm{PO}_{2}\right)$ in a tissue and the nature of the antioxidant, and this is a point of consideration in antioxidant supplementation (Borek, 2004). Carotenoids are an effective chain-breaking antioxidant at low $\mathrm{PO}_{2}$ (Ferreira 
and Matsubara, 1997; Borek, 2004); at high oxygen pressure they are less efficient and may even act as a prooxidant due to autooxidation (Borek, 2004). In contrast, vitamin $\mathrm{E}$ is an efficient antioxidant in cells with a high $\mathrm{PO}_{2}$, for example, in the lung (Borek, 2004). Therefore, in the context of our study, carotenoid-rich supplements are more suitable than vitamins $\mathrm{E}$ and $\mathrm{C}$.

Additionally, Guarnieri et al. (2007) observed that the intake of a single portion of orange juice provided early protection to mononuclear blood cells against oxidative DNA damage. However, this protective effect was not observed after vitamin $\mathrm{C}$ ingestion, indicating that the protective effect of orange juice was not explained by vitamin $C$ alone. Thus, other phytochemicals could be involved, suggesting that whole foods can increase cell resistance to oxidative stress better than single compounds. Although we did not test pure carotenoid supplements, if they are tested in the future, results will probably be concordant with Guarnieri's suggestions and conclusions.

We found that the protection supplied by pequi oil was affected by gender, at least for the AST, ALT, CK, and TBARS assays. In this context, the role of the sex steroid hormones should also be taken into account, as they exert a variety of important actions. Apart from its classic function as a sex steroid, estrogen has been shown to exert antioxidant properties and to protect skeletal muscle from damage (Persky et al., 2000). We also found that damages evaluated by $\mathrm{CK}$ were lower in women than in men in both races. Hence, our results, significant based on the AST, ALT and comet tests for females after pequi-oil supplementation, could be explained by the antioxidant help of the estrogen.

On the other hand, our results from CK and TBARS assays showed pequi-oil protection mainly for males, suggesting that the mechanisms of lipid peroxidation and muscle damage response operate in a similar way, and they are independent of the mechanisms that operate in the other tissues and organs submitted to the ischemia/reperfusion phenomenon.

The antioxidant system, working in parallel with the repair system and exercise training, is a known inducer of antioxidant enzymes. However, although regular exercise causes adaptations, which decrease the incidence of oxidative stress (Ferreira et al., 2007; Radak et al., 2007), increased antioxidant enzyme activities are not enough to completely eliminate the ROS produced after intense exercise (Ferreira et al., 2007). In this context, age group and covered distance can also be considered, because aged muscles exhibit reduced antioxidant adaptation to training, when compared to young muscles, and strenuous physical exercise can impose oxidative stress on the skeletal muscle and other organs due to increased ROS (Cruzat et al., 2007; Ferreira et al., 2007; Judge and Leeuwenburgh, 2007; Radak et al., 2007). We found that the protection supplied by pequi oil was more efficient for younger groups and for distances of up to $10 \mathrm{~km}$. We suggest that long-distance running can be harmful for subjects, especially older athletes, as there is increased oxidative stress above the organism's adaptation capacity, even with the use of antioxidant supplements.

Data showing that trained athletes who ingest antioxidant supplements have reduced oxidative stress suggest the need for further research to fully document the efficacy and safety of longterm antioxidant supplement use (Clarkson and Thompson, 2000). On the other hand, excessive antioxidant intake can have pro-oxidant effects (Antunes and Takahashi, 1999; Paolini et al., 2003), besides the deleterious effects on glucose utilization during muscle contraction (Lecarpentier, 2007). In this context, pequi pulp oil also promoted a decrease in the injuries and lipid peroxidation, even for those athletes who normally use antioxidant supplements, with no pro-oxidant effects.

MnSOD (EC 1.15.1.1) is a mitochondrial enzyme catalyzing the dismutation reaction of superoxide radicals $\left(\mathrm{O}_{2}^{-}\right)$to hydrogen peroxide $\left(\mathrm{H}_{2} \mathrm{O}_{2}\right)$. It is coded by a nuclear gene located on 
chromosome 6q25.3 (Akyol et al., 2005; Bastaki et al., 2006). The enzyme is synthesized with a mitochondrial targeting sequence (MTS). In the mitochondrial matrix, the MTS is cleaved, and the mature protein assembles into the active tetramer (Akyol et al., 2005). The valine to alanine substitution in the MnSOD MTS induces a conformational change from an $\alpha$-helix to a $\beta$-sheet, which has been reported to change mitochondrial processing efficiency, to affect the transport of MnSOD to the mitochondria, and to decrease MnSOD efficiency against oxidative stress (Akyol et al., 2005). Previous studies revealed that the variant -9Ala allele associates with diseases related to oxidative stress and abnormal free radical defense mechanisms, such as exudative age-related macular degeneration, Parkinson's disease and risk of breast, prostate and ovarian cancers (Mitrunen et al., 2001; Olson et al., 2004; Akyol et al., 2005; Choi et al., 2008).

Given that our research was carried out with athletes and that MnSOD is under selective pressure, we suggest that MnSOD heterozygosis favors defense against oxidative stress. This suggestion is based on the results of AST, ALT, comet, and TBARS assays, since the Val/Ala genotype presented the lowest damages to DNA and tissues, as well as the lowest lipid peroxidation levels; this group also had a better response to pequi oil against exercise-induced damages.

\section{CONCLUSION}

In summary, pequi oil was efficient in reducing tissue injuries, based on AST and ALT values, particularly in women, and in reducing DNA damages in both sexes. Except for CK, the results were influenced by MnSOD genotypes; heterozygous individuals had less DNA damage and tissue injuries and lower lipid peroxidation levels. They also had a better response to pequi oil against exercise-induced damages. Therefore, pequi oil, as well as possessing many other nutritional properties, is a good candidate for use as an antioxidant supplement.

\section{ACKNOWLEDGMENTS}

The authors gratefully acknowledge the subjects who participated in this research, Sabin Institute/Sabin Laboratories and Farmacotécnica for technical support and the University of Brasília (UnB), the National Council for Technological and Scientific Development (CNPq) and the Scientific and Technological Enterprises Foundation (FINATEC) for financial support.

\section{REFERENCES}

Akyol O, Yanik M, Elyas H, Namli M, et al. (2005). Association between Ala-9Val polymorphism of Mn-SOD gene and schizophrenia. Prog. Neuropsychopharmacol. Biol. Psychiatry 29: 123-131.

Almersjo O, Bengmark S, Engevik L, Hafstrom LO, et al. (1968). Serum enzyme changes after hepatic dearterialization in man. Ann. Surg. 167: 9-17.

Antunes LM and Takahashi CS (1999). Protection and induction of chromosomal damage by vitamin C in human lymphocyte cultures. Teratog. Carcinog. Mutagen. 19: 53-59.

Azevedo-Meleiro CH and Rodriguez-Amaya DB (2004). Confirmation of the identity of the carotenoids of tropical fruits by HPLC-DAD and HPLC-MS. J. Food Comp. Anal. 17: 385-396.

Bastaki M, Huen K, Manzanillo P, Chande N, et al. (2006). Genotype-activity relationship for Mn-superoxide dismutase, glutathione peroxidase 1 and catalase in humans. Pharmacogenet. Genomics 16: 279-286.

Borek C (2004). Antioxidants and radiation therapy. J. Nutr. 134: 3207S-3209S.

Brancaccio P, Maffulli N and Limongelli FM (2007). Creatine kinase monitoring in sport medicine. Br. Med. Bull. 81-82: 209-230.

Genetics and Molecular Research 8 (4): 1481-1495 (2009)

CFUNPEC-RP www.funpecrp.com.br 
Bruce R, Todd JK and Ledune L (1958). Serum transaminase: its clinical use in diagnosis and prognosis. Br. Med. J. 2: $1125-1128$.

Choi JY, Neuhouser ML, Barnett MJ, Hong CC, et al. (2008). Iron intake, oxidative stress-related genes (MnSOD and MPO) and prostate cancer risk in CARET cohort. Carcinogenesis 29: 964-970.

Clarkson PM and Thompson HS (2000). Antioxidants: what role do they play in physical activity and health? Am. J. Clin. Nutr. 72: 637S-646S.

Collins AR (2009). Investigating oxidative DNA damage and its repair using the comet assay. Mutat. Res. 681: 24-32.

Collins AR, Ma AG and Duthie SJ (1995). The kinetics of repair of oxidative DNA damage (strand breaks and oxidised pyrimidines) in human cells. Mutat. Res. 336: 69-77.

Cruzat VF, Rogero MM, Borges MC and Tirapegui J (2007). Current aspects about oxidative stress, physical exercise and supplementation. [Aspectos atuais sobre estresse oxidativo, exercícios físicos e suplementação]. Rev. Bras. Med. Esporte 13: 336-342.

dos Santos HS and Cruz WMS (2001). The antioxidant vitamin nutritional therapy and the chemotherapy treatment in oncology. [A terapia nutricional com vitaminas antioxidantes e o tratamento quimioterápico oncológico]. Rev. Bras. Cancerol. 47: 303-308.

Ferreira ALA and Matsubara LS (1997). Radicais livres: conceitos, doenças relacionadas, sistema de defesa e estresse oxidativo. Rev. Ass. Med. Bras. 43: 61-68.

Ferreira F, Ferreira R and Duarte JA (2007). Oxidative stress and damage in skeletal muscle: Influence of unusual acute exercise and physical conditioning. [Stress oxidativo e dano oxidativo muscular esquelético: influência do exercício agudo inabitual e do treino físico]. Rev. Port. Cien. Desp. 7: 257-275.

Forsberg L, de Faire U and Morgenstern R (2001). Oxidative stress, human genetic variation, and disease. Arch. Biochem. Biophys. 389: 84-93.

Foschini D, Prestes J and Charro MA (2007). Relationship between physical exercise, muscle damage and delayedonset muscle soreness. [Relação entre exercício físico, dano muscular e dor muscular de início tardio]. Rev. Bras. Cineantropom. Desempenho Hum. 9: 101-106.

Freire LMD, Sodréb FL, Oliveira RA, Castilho LN, et al. (2008). Pre-analytical laboratory quality control: evaluation of medical requests for biochemical laboratory exams in the University of Campinas State University Hospital, São Paulo, Brazil. [Controle de qualidade laboratorial pré-analítico: avaliação de solicitações médicas de exames bioquímicos no Hospital de Clínicas da Universidade Estadual de Campinas, São Paulo, Brasil]. Rev. Bras. Anal. Clin. 40: 143-145.

Guarnieri S, Riso P and Porrini M (2007). Orange juice $v s$ vitamin C: effect on hydrogen peroxide-induced DNA damage in mononuclear blood cells. Br. J. Nutr. 97: 639-643.

Jaloszynski P, Kujawski M, Czub-Swierczek M, Markowska J, et al. (1997). Bleomycin-induced DNA damage and its removal in lymphocytes of breast cancer patients studied by comet assay. Mutat. Res. 385: 223-233.

Ji LL and Leichtweis S (1997). Exercise and oxidative stress: Sources of free radicals and their impact on antioxidant systems. $A G E$ 20: 91-106.

Judge S and Leeuwenburgh C (2007). Cardiac mitochondrial bioenergetics, oxidative stress, and aging. Am. J. Physiol. Cell Physiol. 292: C1983-C1992.

Kargotich S, Goodman C, Keast D and Morton AR (1998). The influence of exercise-induced plasma volume changes on the interpretation of biochemical parameters used for monitoring exercise, training and sport. Sports Med. 26: 101-117.

Lecarpentier Y (2007). Physiological role of free radicals in skeletal muscles. J. Appl. Physiol. 103: 1917-1918.

Lima A, Silva AMO, Trindade RA, Torres RP, et al. (2007). Chemical composition and bioactive compounds in the pulp and almond of pequi fruit. [Composição química e compostos bioativos presentes na polpa e na amêndoa do pequi (Caryokar brasiliense, Camb.)]. Rev. Bras. Frutic. 29: 695-698.

Mastaloudis A, Yu TW, O'Donnell RP, Frei B, et al. (2004). Endurance exercise results in DNA damage as detected by the comet assay. Free Radic. Biol. Med. 36: 966-975.

Miranda-Vilela AL, Resck IS and Grisolia CK (2008). Antigenotoxic activity and antioxidant properties of organic and aqueous extracts of pequi fruit (Caryocar brasiliense Camb.) pulp. Genet. Mol. Biol. 31: 956-963.

Miranda-Vilela AL, Resck IS, Mendonça MA and Grisolia CK (2009). Characterization of the major nutritional components of Caryocar brasiliense fruit pulp by NMR spectroscopy. Quim. Nova 39: 2310-2313.

Mitrunen K, Sillanpaa P, Kataja V, Eskelinen M, et al. (2001). Association between manganese superoxide dismutase (MnSOD) gene polymorphism and breast cancer risk. Carcinogenesis 22: 827-829.

Mougios V (2007). Reference intervals for serum creatine kinase in athletes. Br. J. Sports Med. 41: 674-678.

Oliveira MNS, Gusmão E, Lopes PSN, Simões MOM, et al. (2006). Maturity stage of fruits and factors related to nutritive and texture characters of pequi (Caryocar brasiliense Camb.) pulp. [Estádio de maturação dos frutos e fatores relacionados 
aos aspectos nutritivos e de textura da polpa de pequi (Caryocar brasiliense Camb.)]. Rev. Bras. Frutic. 28: $380-386$.

Olson SH, Carlson MD, Ostrer H, Harlap S, et al. (2004). Genetic variants in SOD2, MPO, and NQO1, and risk of ovarian cancer. Gynecol. Oncol. 93: 615-620.

Paolini M, Abdel-Rahman SZ, Sapone A, Pedulli GF, et al. (2003). $\beta$-carotene: a cancer chemopreventive agent or a cocarcinogen? Mutat. Res. 543: 195-200.

Persky AM, Green PS, Stubley L, Howell CO, et al. (2000). Protective effect of estrogens against oxidative damage to heart and skeletal muscle in vivo and in vitro. Proc. Soc. Exp. Biol. Med. 223: 59-66.

Radak Z, Kumagai S, Nakamoto H and Goto S (2007). 8-Oxoguanosine and uracil repair of nuclear and mitochondrial DNA in red and white skeletal muscle of exercise-trained old rats. J. Appl. Physiol. 102: 1696-1701.

Ramos MIL, Umaki MCS, Hiane PA and Ramos-Filho MM (2001). The effect of the conventional cooking under carotenoids provitamin "A" of the pulp of piqui (Caryocar brasiliense Camb.). [Efeito do cozimento convencional sobre os carotenóides pró-vitamínicos "A" da polpa do piqui (Caryocar brasiliense Camb.)]. Bol. Centro Pesqui. Process. Aliment. 19: 23-32.

Schumann G and Klauke R (2003). New IFCC reference procedures for the determination of catalytic activity concentrations of five enzymes in serum: preliminary upper reference limits obtained in hospitalized subjects. Clin. Chim. Acta 327: 69-79.

Singh NP, McCoy MT, Tice RR and Schneider EL (1988). A simple technique for quantitation of low levels of DNA damage in individual cells. Exp. Cell Res. 175: 184-191.

Traber MG (2006). Relationship of vitamin E metabolism and oxidation in exercising human subjects. Br. J. Nutr. 96 (Suppl 1): S34-S37.

Ukkola O, Erkkila PH, Savolainen MJ and Kesaniemi YA (2001). Lack of association between polymorphisms of catalase, copper-zinc superoxide dismutase (SOD), extracellular SOD and endothelial nitric oxide synthase genes and macroangiopathy in patients with type 2 diabetes mellitus. J. Intern. Med. 249: 451-459.

Urso ML and Clarkson PM (2003). Oxidative stress, exercise, and antioxidant supplementation. Toxicology 189: 41-54.

Wasowicz W, Neve J and Peretz A (1993). Optimized steps in fluorometric determination of thiobarbituric acid-reactive substances in serum: importance of extraction $\mathrm{pH}$ and influence of sample preservation and storage. Clin. Chem. 39: $2522-2526$.

Zhao H, Liang D, Grossman HB and Wu X (2005). Glutathione peroxidase 1 gene polymorphism and risk of recurrence in patients with superficial bladder cancer. Urology 66: 769-774. 